The Medieval Life of Language 


\section{Knowledge Communities}

The Knowledge Communities series focuses on innovative scholarship in the areas of intellectual history and the history of ideas, particularly as they relate to the communication of knowledge within and among diverse scholarly, literary, religious and social communities across Western Europe. Interdisciplinary in nature, the series especially encourages new methodological outlooks that draw on the disciplines of philosophy, theology, musicology, anthropology, paleography and codicology.

Knowledge Communities addresses the myriad ways in which knowledge was expressed and inculcated, not only focusing upon scholarly texts from the period, but also emphasizing the importance of emotions, ritual, performance, images and gestures as modalities that communicate and acculturate ideas. Knowledge Communities publishes cutting-edge work that explores the nexus between ideas, communities and individuals in medieval and early modern Europe.

Series Editors

Clare Monagle, Macquarie University

Mette Bruun, University of Copenhagen

Babette Hellemans, University of Groningen

Severin Kitanov, Salem State University

Alex Novikoff, Fordham University

Willemien Otten, University of Chicago Divinity School 


\section{The Medieval Life of Language}

Grammar and Pragmatics

from Bacon to Kempe

Mark Amsler

Amsterdam University Press 
Cover image: From BL, Stowe MS 49, fol. 22or (c. 1300)

(c) The British Library Board

Cover design: Coördesign, Leiden

Typesetting: Crius Group, Hulshout

$\begin{array}{ll}\text { ISBN } & 9789463721929 \\ \text { e-ISBN } & 9789048550166 \text { (pdf) } \\ \text { DOI } & 10.5117 / 9789463721929 \\ \text { NUR } & 613 \text { I } 616\end{array}$

(c) Mark Amsler / Amsterdam University Press B.V., Amsterdam 2021

All rights reserved. Without limiting the rights under copyright reserved above, no part of this book may be reproduced, stored in or introduced into a retrieval system, or transmitted, in any form or by any means (electronic, mechanical, photocopying, recording or otherwise) without the written permission of both the copyright owner and the author of the book.

Every effort has been made to obtain permission to use all copyrighted illustrations reproduced in this book. Nonetheless, whosoever believes to have rights to this material is advised to contact the publisher. 